\title{
神奈川県立がんセンター頭项科 *横浜市立大学耳鼻咽喉科学教室
}

○古川まどか、久保田 彰、古川政樹*、鈴木陽子*、大石公直 *

顅面㴼の原因はさまざまであるが、安易に三叉神 経痛之診断され、漫然之投薬を受けている例も少 なくない。今回われわれは、慎重な榆索の結果、 顔面痛の原因が副與㓐の小衰胞であることを疑い、 手術により症状の軽快をみた 2 例を経験したので 報告する。

症例 153 歳 女、1988.9.16 初診

主訴 : 左顔面痛、既往歴 : 高血圧

現病歴：4-5年前よりさしこむような左顔面痛 がときどき出現するようになった。耳鸟咽喉科 3 か所、脳外科を受診するも診断確定にはいたらず、 テグレトールなどの投与をうけていたか、症状の 改善はみられなかった。

初猃洔所見 : 顔面の痛みは左眼窝を中心とするも のであった。鼻所見では左下鼻甲介と界中隔の病 着がみられる以外、異常所見はなかった。 画像診断:単純 X 線撮影で右前頭洞に異常䧍影を認 めた（図 1 ）。X線CTでも同じ部位にLDAがあ った。

経過：鼻外前頭洞開放術を行ったところ、画像診 断の異常险影部位に一致して褧胞が存在し、内部 には黄色混濁した盯留液がられた。術後、顔面 痛は消失した。

症例 254 歳 男 1990.1 .18

主訴 : 右顔面痛、既往歷 : 高血圧

現病歷：1990.1.17 より強い右顔面痛が周期的に 出現した。

初診時所見：痛みの中心は鼻根部右侧であった。 耳・鼻・咽喉頭には異常所見を認めなかった。 画像診断：単純撮影では明らかな異常所見はみら れなかったか、痛みの性状が典型的な三叉神経痛 とは異なるため、X線CTを施行したところ蝶形骨 洞に球形の異常陰影を認めた（図 2)。MRIでも 同じ部に票胞を疑わせる異常陰影があった。

経過：経鼻的に蝶形骨洞を開放すると、蝶形骨 洞内部の隔壁に、はまりこむようにして、前壁に
茎をもつ小襄胞が存在したのでこれを摘除した。 黄白色混溜した内溶液がみられた。術後、颜面痛 は完全に消失した。

症例 1 はわれわれの施設を受診するまえに複数 の施設で検査を受けていたにもかかわらず、長期 にわたって痛みの原因としての前頭洞变胞が見逃 されていた。しかも正診にいたるきっかけは単純 $\mathrm{X}$ 線撮影であった。症例 2 は単純 X 線撮影では異 常を認めなかったか、、念のため撮影したX $\mathrm{X}$ 線 CT により痛みの責任病樔が発見された。2症例とも 小变胞が激しい顔面痛の原因であり、基本に沿っ て診断を遮めていくことの重要性を再認識させる 貴重な症例であると考え報告した。

図 1 左前頭洞に異常陰影を認める(

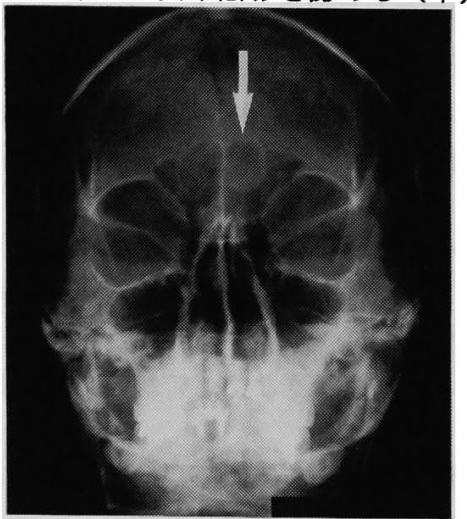

図 2 蝶形骨洞に異常陰影を認める（^）

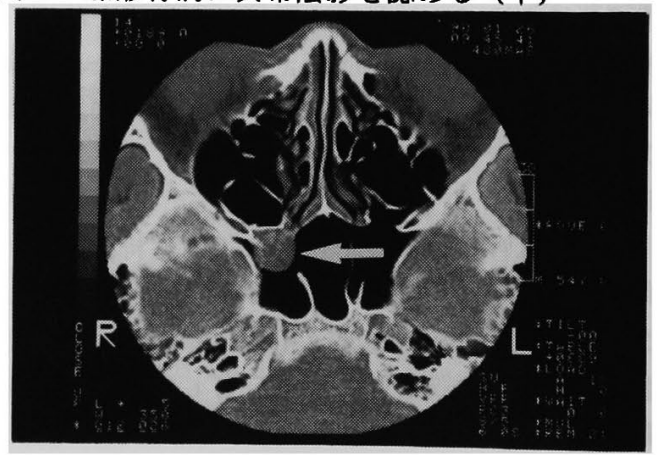




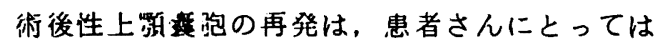
肉体的にも，精神的にもかなりの苦捔をむたらす ものてあり，また治療する側にとってもその対処 の仕方に苦㴔するととが多いと思われる。今回私 共㹥過去 5 年間の術後性上等胞例について術後 経過を調查し、再発例の発生书よびその要因とそ の対策について検㣙を加えてみた。

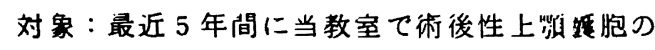
診断のもとに再手術を施行した怔例は147例 (158 測)であり，その内男性 90 例 (97 側)，女 性 57 例 (61 側) でった。その内て今回の呼び出 しに応じ再来したものは 39 例 (43 側)であった。 この症例を中心に検討した。

方法：症状（煩部のシビレ感，巽和感，王痛な ど)の聴取、フレキシブルファイバーての対孔の 開存の有無. さらに術前術後の断首写真, C T

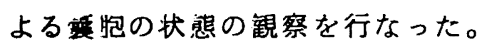

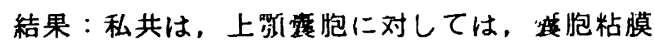
を线し，空控へ排㴹孔をつける方法を行なってい

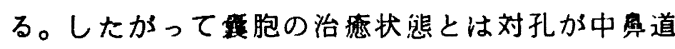
あるいは下賏道に通じているととが最低の条件と 考える。てれについてみると再来した 39 例（43 側) 中対孔開存例 30 側 $(69.8 \%)$ ，対孔閉鎖例 13

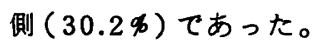

症状についてみると，43 側中 13 側 (30.2\%)

で压痛, 異和感, シビレ感など何らかの症状を訴 えており，さらに対孔の開状態よりみると，対 孔開存例 30 側中症状(十)例か 5 側 $(17.2 \%)$, 拝状 Hの例か 25 側 (83.3\%), 対孔閉鎖例 13 側中症状 (十の例は 8 側 $(61.5 \%)$, 症状(

ゅ)であった。

対孔閉镍例 13 唄について, 初回手術法との関係を

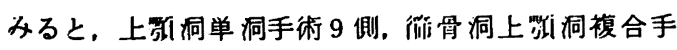
術 4 側であった。レ線写真 (副界胫断層写真と CT. 画 像)およひ手術所見よりみると，単房性隺胞 9 側，多

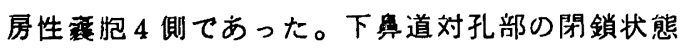
は骨性閉領例が 9 側、嗼性閉鎖が 4 測でらった。
再手術後あるいは再々手術後より閏嗩したと考 えられる腙则は 13 側中 6 側が 1 个月前後て，その

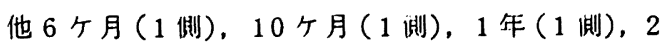
年 (1划)，不明 ( 3 倒)でった。

対策としては，再手術又は症例によっては再々手 術となるた奻，手術を微外にくいてとも多く，したが って出来るだけ外来で開空術を行なっているが,ての 開空術が不可能な場合には, 充分説明の上で通当

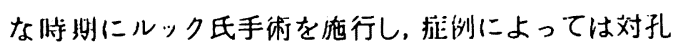
部にシリコンチュープの長期間の留遺を行なっている。

考察: 今回の検討において対孔断鎖 13 則 (30.2 ø）はかなり高奖と忠われるが，再来した泟例が 治热装に不安を持つもの, 拉状あるものが多い

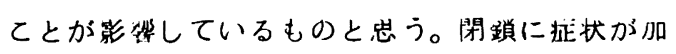
わって再肂と云うとすれば，再発㨇はもう少し低 率となると思う。対孔の阔鎖を防止することはか なり難しいか，炎证などが閉硝を促進させること が考えられ，抗炎拝㓱の長淂投与，対孔の珗條な どー方法と考元る。その他肥の再発の要达と

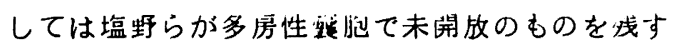
てと, 理由不明ながら炮を生じやすい局, 沂の治 撩機転の問題をあげている。今回の娭討ても，歯 根端炮の合併，比較的小さい胞胞外側に存在 した場合，鼻底部に存在した場合などが考えられ た。いずれにしても術前にレ線学的に充分梌討を 加え洞内を単一な開放腔とする樣に心がけるとと が肝要と思われる。

まとめ

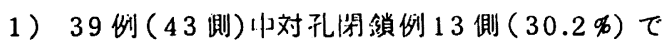
あった。

2) 対孔阙敛例 13 側中症状のないものは 5 則

(38.5\%)でった。

3) 対孔洞谽例 13 側小 6 倒が術後 1 ケ月前後て再 閉鎖していた。

参考文塥

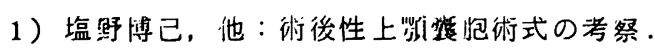
耳诶頭頸 61：4，301～305．1989. 


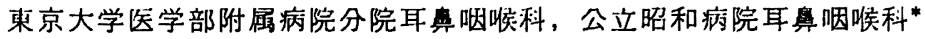
石尾健一郎，善浪弘善; 加濑康弘，市村腎一，饭沼垟

今回, 我々は過去 5 年間に当科で手術を施行した 術後性上頻霝胞症例の臨床症状について恰討した。

\section{【対象並びに方法】}

対象は，1987年から1991年の 5 年間に当科で手 術を施行した術後性上顎㢣胞症例，108例130側， 男性73例92側，女性35例38側，平均年秢仕 48.8 （26 74）歳, 患側は左側38例, 右側48例, 両側 22例であり，一側を一単位として retrospective飞 分析を行った。両側22例のうちが記杫不明暸てあ った 2 例と, 症状の出現は一倒のみてあったが術 前の画像診断により術後性上額琵胞を診断し手術 を施行した無症状側14倒は今回の検討から除外し

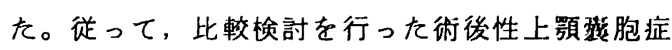
例は106例112側, 男性71例76侧, 女性35例36倒, 左側49側, 右側63側である。

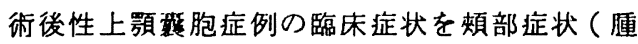
脹, 疼痛, しびれ）, 口腔症状（腫脹, 米痛, し

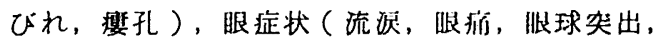

複視, 視力障害)，鼻症状 (鼻閉, 鼻漏, 宜出血), 頭症状（頭痛，頭重感），その他に分け

(1)初発時期と手術施行時期におけるそれぞれの 症状の出現数

(2)症状ごとの発症時期から手術に至るまでの期 間, につんて比較検討した。

\section{【結果】}

初発時期と手術施行時期におけるそれぞれの臨 床症状の出現数を[図1]に一臨する。

頓部症状は初発時期, 手術施行時期のいずれにお

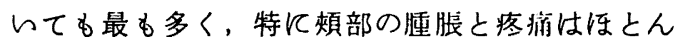
どの症例に認められた。初発時期の症状では頓部 腫脹, 頓部疼痛, 迷痛, 煩部しびれ, 口腔の腫脹, 县漏, 鼻閉の順, 手術施行時期の症状では煩部疼 痛, 煩部腫脹, 歯痛, 口腔の邀脹, 漏, 閉, 煩部しびれの順であった。また，頖部症状，口腔 症状, 眼症状, 症状, 頭症状, その他飞分類し た場合の出現頻度とその候向を〔図 2 〕に示す。 症状ごとの発症時期から手術に至る主ての期間
を[図 3 ] 飞示す。発症時期から手術に至るまで の期間は平均 4.00 年 $(0.08 \sim 47$ 年 )であった。症状 別では, 煩部迎服4.25年, 煩部疼捎 3.75 年, 喕痛 3.25 年, 画痛 3.24 年の順であった。
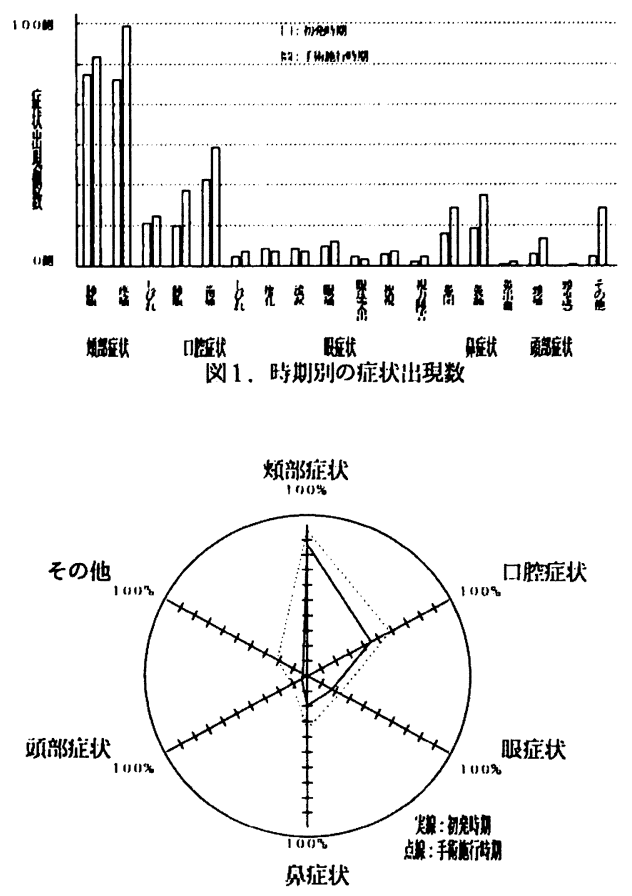

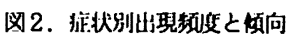

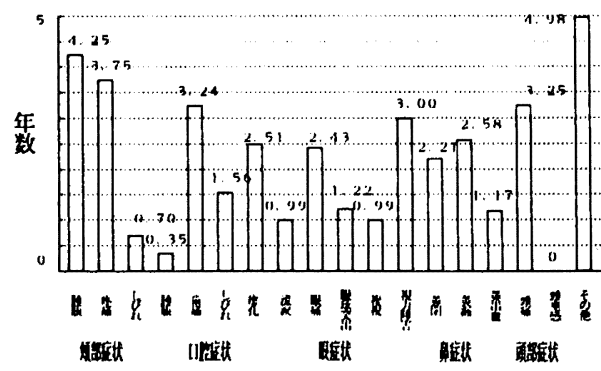

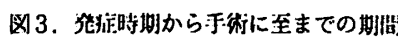


111 術後址煩部诲咆骨壁の走查電顯的観察

埼玉医大総合医療センター耳忽咁喉科

川端五十鈴，山部 沙生

\section{I.はじめに}

上䫑洞根治術の施行から10ないし20㤰後に発症 する術後性煩部篂胞の生因として，術野に残存し た上額洞粘膜か再生して生じる眝溜紧胞説か有力 であるしたかって本症の矿究は抵胞禁の粘膜の 検索が主体であり, 病理組維学的研究をはじめ, 種々の方法でおてなわれてきた。残存粘膜は增殖 して悎胞化し，内腔に分泌物を詝溜しなから应大 し，洞外へ進展して臨床症状を生しるものと考え られている。したかっって上顎洞骨壁の消失を来た して，洞外へ進展するものである。しかしての骨 壁に関する検索は少ないようである。私其は潞胞 の正迫应大に伴う骨壁の変化を知るため, 走查笔 顥で橉胞の骨壁の表面構造を奥腔侧のそれと対比 しなから観察したとてろ，2-3の興味ある所見 が得られたので，てとに報告する次第である。

II. 研究材料之研究方法

術後性煩部隻胞の診断のもとに当科で上顎洞根 治術を施行した10症例を刘象とした。拱胞内拧溜

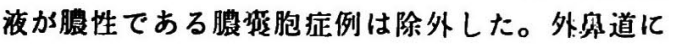
対孔を造設する際，乙の部の骨壁を鹳察対象とし た。試料は10\%ホルマリンで固定したのち, 契体

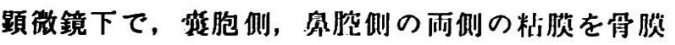
とともに屾来るだけ剥離した。さらに骨㳖面を露 出させるため、コラゲナーゼ溶液と壏酸（IN）で 処理したのち, アルコール脱水, 臨界点乾燥, 金 属蒸着をおこなって走查電蜎で観察した。

III. 観察結果

粘膜とともに骨膜を除去すると骨組繳の㤗面か

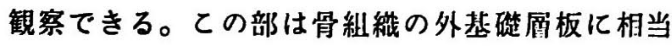
する所であり，膠原線維か綎剎に走行しているか， ある程度の方向性をもって走行している。個々の 線維は篗胞側では直線状に配列しているか，奥腔側 ではよじれたり，蛇行するものが多いように思わ れた。またての部では骨表而をはうょうに細血管 かみられ，骨組織内へ浸入していた。てのような 所見は鼻腔側の骨表面に多かった。

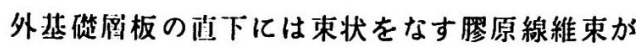
みられ，線維來はおたかいに吻合をくり返しなが ら走行している。骨紬䋨は常に石灰化代謝をおこ なっているとされ，走查電顥では石灰化した照合 膠原線維來の裴而は粗䊉にみえるとされるので, 今回との視点から惟胞側と感腔侧の骨裴面を比較 湌討してみた。

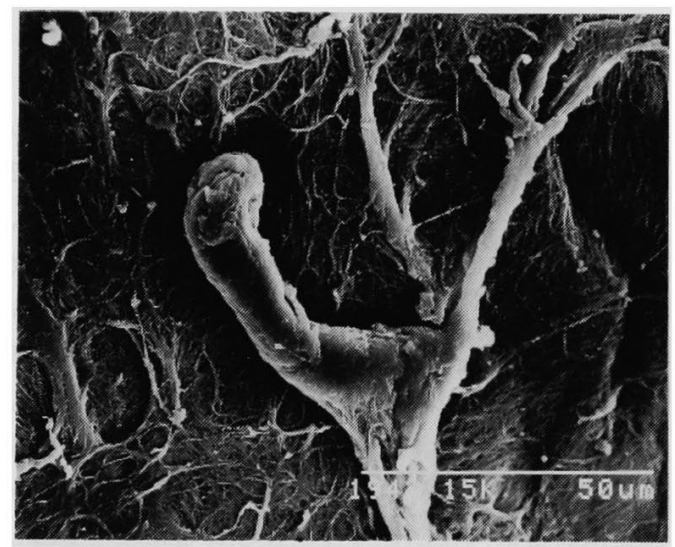

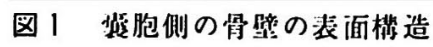

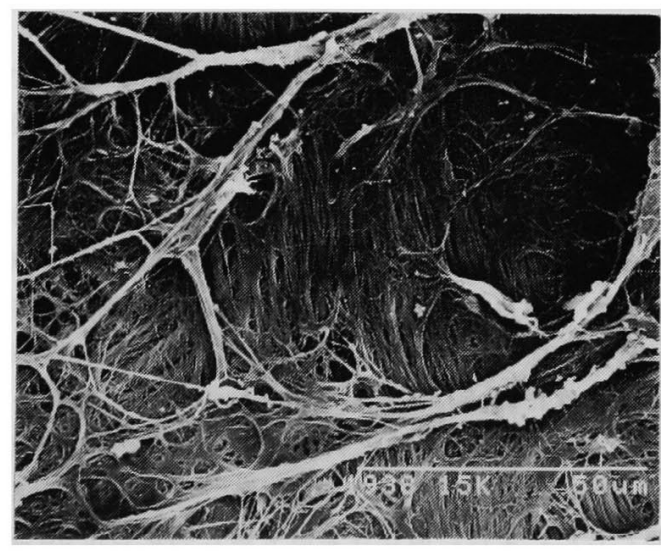

图 2 则整侧の骨裴面権造 


\section{日本畄科学会会誌}

\section{2 術後性上影要胞}

一特に潜在性裂胞について一第吕報

大阪的科大学耳咽喉科学数室

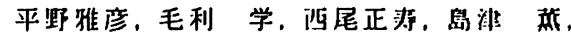

街本保二，森本伊智郎

目的

本疾槵は両侧に発症する邪が少なく、1 侧性病 変として取り扱われている可が多い。しかしなが ら、臨床症状を欠く非㭧侧における后胞發症の有 無は興味樑い問題である。我々は、第 22 回本学会 において術後性上帏登胞 81 例の非患侧における潜 在性强胞について検討した。今回我々はさらに症 例を追加し、206 例とし潜在性胞かどの程度存 在するのか、どの程度影性爱胞に登既するのかに ついて検討を加えたので報告する。

対象

1976 年 1 月より1992 年 4 月までに当科を受診し た浦後性上额衰胞 206 例である。性別は男性 122 例、女性 84 例で男女比は $3: 2$ と男性にやや多く、 発症年路は 40 歲代が最も多く 84 例 $(40.8 \%)$ て、次 いで30歳代58例 (28.2\%)，50歳代40例(19.4\%)であ った。また初回手術から発店までの経過年数は15 年より 30 年までが 136 例と過半数を占めていた。 これらの症例において潜在性爱胞の有㢳を判定基 染(表 1)に従い检討した。但し、X線掫影は後顽・ 前頭単純提影，Waters氏法及び根部より $2 \mathrm{~cm}$ ， $3 \mathrm{~cm}, 4 \mathrm{~cm}$ の後頭・前頭断首撮影を用い、界腔所 見は前踥検査及び努腔ファイパースコープ用い 钼察した。

結果

1）患側の左右差は左侧が 92 例、右侧が 97 例で 左右差はほぼ1：1であり、両侧同時に手術を必要

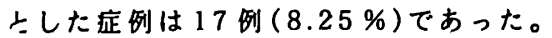

2) 対象症例 206 例中、両侧同時庭例 17 例を除 いた 189 例の非患侧において、潜在性高胞の有䇤 を判定基华に基つき判定した結果、非槵侧に替在 性竞胞を認めた应例は 189 例中 121 例で $64.02 \%$ と高頻度に認めた。

3）潜在性胞有りと判定された 121 例中 11 例 (9.09\%)が経過観察中に顕性巽胞に発展し手術を必 要とした。また、潜在性衰胞を無と判定した 68 症

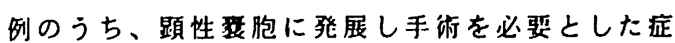

例は、現在のところ認めていない。

4) 潜在性强胞より頙性饻胞に發展した症例は、 男性 5 例、女性 6 例で纷女比はほぼ同じであった。 また潜在性寑胞と判定した時点より影性要胞に発 展し手術を必要とするまでの期間は最小期間か 4 ヶ月で最長期問が 7 年であった（表 2 ）。衰胞数

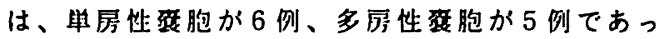
た。

\section{結語}

㭪後性上颣胞胞の男女比、左右差、好発年路、 発症までの期閉などは従来より報告されている統 計学的観察とほほ同㥞であった。両侧同時に手術 を必要とした应例は諸家の報告によれば1.7\%から $12.5 \%$ で平均1割弱であり、我々も 17 例 $(8.25 \%)$ と ほほ同様であった。また、これら両侧同時手術症 例を除く 189 例中 121 例 $(64.02 \%)$ 上高頻度に潜在

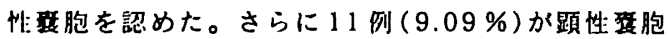
へ發展し手術を必要とした。以上のことより術後 性上嚬要胞を診断する上で反対侧（非患侧）に対す ろ注意か必要かと示唆された。

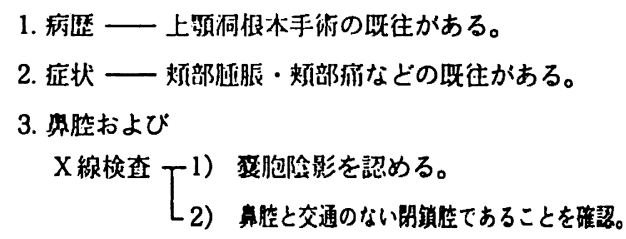

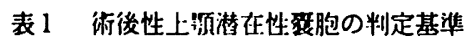

\begin{tabular}{|c|c|c|c|c|c|c|c|}
\hline 期間 & 4 力月 & 1 年 & 2 年 & 3 年 & 4年 & 6 年 & 7 年 \\
\hline 侧数 & 1 & 3 & 1 & 1 & 1 & 1 & 3 \\
\hline
\end{tabular}

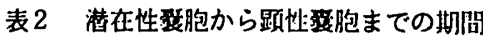


113 手術比往症例における前頭洞监匏由来の気嗬症

\section{杏林大学医学部耳忽吸喉科教室}

江部 学, 捠田利彦, 松田此绯, 是昌已

\section{はじめに}

副鼻腔は，眼窝，視神経，頭蓋に隣接しており， 手術に際しては，常に剧損伤の危険を伴ならもの と思われる。また初回手術に比悛し, 再手術の場 合には，さらにその危険性は高いものと思われる。 今回, 我々は上筫洞, 笁骨洞飞対する手術既往の ある前頭洞㯎胞飞遭遇, 鼻内前頭洞手術施行, 経 算的に湿胞を開放した際に，限局した気䏚部分を 認めた症例を経験したので報告する。

\section{症例}

43才男性, 左上眼窝から前頭部に及ぶ疼痛を主 訴汇受診。18才時, 上䂓洞, 穊骨洞手術の既往有 り。鼻鏡検上, 鼻内所見では, 左中臭道は癒着, 閉鎖しておうり,ン゙ンディーレンは不可能であった。 同時に中等度の鼻中隔弯曲を認めたが㳄骨は既に 久損しており，宜中隔鴊曲に対する手術も受けた ものと思われた。 X-Pでは, 左節骨洞天蓋から 鼻前頭管附近にかけて, 䧔影の增強と骨の肥厚を 認めた。C T 上, 篩骨洞, 前頭洞は, 均一な, Sof $\mathrm{t}$-Tissue massにて充涩して扰り，前頙洞㷋壁の 一部は骨欠損を疑わせる所見を示していた。

手術時, 鼻中隔弯曲を修正した後, 前篍骨蜂紧 を清掃，具前頭管は硬性に閉塞していたがこれ を開放した直後に，粘䝢性の分泌を認めた。周囲 の不良肉芽を除去し, 手術を終了した。

術後処置にても自前頭管のゾンディーレンは容 易で，主訴の疼痛は消失した。しかし，ソンテデの 探索により前頭洞天蓋部より脳内へ向けてさらに 空洞の存在が疑われたため,この部の隔壁を穿破 し,内視鏡に上り気脳部分を確認した。C $\mathrm{T}$ 上む 頭蓋内の含気スベースの存在を認め, 気脳症と猃 断した。その後は外科的処狊を行わず, 強力な抗 生剤の投与により, 感染を示す徵候も哭く経過し, 約一週間後のCT, M R I Kて含気スペースの消 失を確認した。
考察

前回の手術により，秉前頭管の人工的な閉塞を 招来し, その結果, 整胞化から洞後壁の厷範な省 欠掑を来たしたものと考へられた。

長期にわたる前站洞胞の存在により, 脑硬膜 が脳実質内一進入溜顿し, 今回の洞開放の結果,

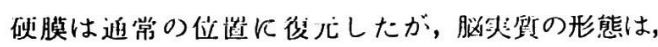
そのまま残され，気脳柾となったものと推定した。

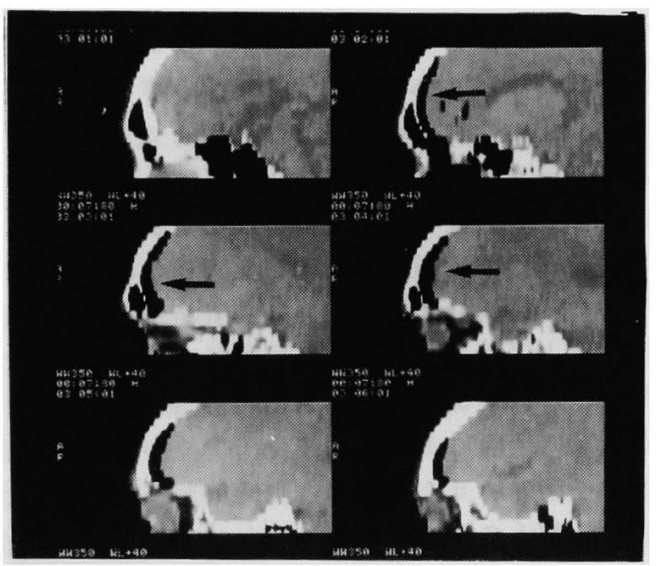

気腷状態を示す矢状断 C T 